\title{
Chinese overseas ports: Market potential, supply capacity and access to imports
}

\author{
DUNFORD Michael ${ }^{1,2}$, 'LIU Zhigao ${ }^{1,2,3}$, XUE Jiashun ${ }^{1,4}$ \\ 1. Institute of Geographic Sciences and Natural Resources Research, CAS, Beijing 100101, China; \\ 2. Key Laboratory of Regional Sustainable Development Modeling, CAS, Beijing 100101, China; \\ 3. College of Resources and Environment, University of Chinese Academy of Sciences, Beijing 100049, China; \\ 4. University of Chinese Academy of Sciences, Beijing 100049, China
}

\begin{abstract}
Especially since 2012 Chinese companies have acquired stakes as investors and constructors of overseas ports in both high-income and emerging economies. These initiatives play an important role in the construction of a Maritime Silk Road and China's Belt and Road Initiative (BRI). Although a result of many factors, of which Chinese port investments are only one, macro-geographical gravity methods show that distance impedance and increases in the export market potential, export supply capacity and access to imports of these countries drove increases in income per capita. Export supply capacity rose particularly in Southeast Asia and more recently in Sub-Saharan Africa. In difficult times for the world economy, countries in which China invested in overseas port infrastructure saw increases in national export market potential and income per capita, due to reduction in the impedance of distance, while in the case of developing economies export market supply capacity and access to imported capital equipment and intermediate goods improved.
\end{abstract}

Keywords: trade; gravity models; market potential; cumulative causation; port investment; China; Belt and Road Initiative (BRI)

\section{Introduction}

A number of Chinese companies have recently played major roles in the development of overseas ports. With the implementation of China's Belt and Road Initiative (BRI), many of these ports are playing significant roles in the construction of a Maritime Silk Road and its articulation with overland infrastructure investment (Liu and Dunford, 2016; Liu et al., 2020). The aim of this article is to outline the development of these ports and examine the trade development of the countries in which they are located, using gravity and economic potential models. Only a small amount of attention is paid to the comparative performance of countries without Chinese investments, as the aim is simply to identify impacts on export

\footnotetext{
Received: 2020-03-22 Accepted: 2020-06-16

Foundation: National Natural Science Foundation of China, No.41530751; The Priority Research Program of Chinese Academy of Sciences, No.XDA19040403; National Social Science Foundation of China, No.17VDL008

Author: Dunford Michael, specialized in economic geography and regional development. E-mail: m.f.dunford@sussex.ac.uk

"Corresponding author: Liu Zhigao, PhD, E-mail: liuzhigao@igsnrr.ac.cn
} 
market potential (access to international markets as sources of demand for exports), export supply capacity of the hinterlands of these ports and access to global markets affording needed imports of capital, intermediate and consumer goods (access to imports). These outcomes are a result of very many factors, of which Chinese port investment is only one, and possibly a small one. The aim is simply to see whether the outcomes are consistent with the likely developmental impacts of new investments, especially in the least developed countries.

To this end, the next section briefly examines the role of port infrastructure and logistic services in economic development. The second section outlines the evolution of economic potential models, sets out the modelling framework and identifies the sources of the data used in this research. The third outlines the development of Chinese overseas ports, while the fourth and fifth present the empirical results of the trade and economic potential modelling. The sixth section concludes.

\section{Port infrastructures, sea transport and economic development}

The development of an international division of labour involves not just the development of clusters of internationally inter-related value added chains but also the development of local and global logistic services in which port and other transport infrastructures play a fundamental role, acting as vital nodal and channel spaces (Robinson, 2002).

At one level, ports act as interfaces between national economies and adjacent territories and the international economy, handling and embedding commodity and related information flows (Ducruet et al., 2015). As interfaces, ports play a number of roles. First, they compete to attract global and regional shipping and logistic services and to connect their hinterlands with import and export markets. Second, they act as customs clearance zones. Third, they engage in the trans-shipment, intermodal transfer and storage of commodities. The goods that pass through ports account for some $80 \%$ of world trade by volume, and by value they account for $70 \%$, with an even higher share for developing countries. These shares vary with the evolution of the world economy (UNCTAD, 2019). China as the manufacturing workshop of the world plays a major role in these global transactions.

Although the size of markets and the associated geographies of export and import supply and demand shape trade (Figure 1), participation in international freight transport and trade also depends on the degree of connectivity to international markets. Connectivity depends on the existence of appropriate infrastructures and the ability to attract international and regional shipping lines. Shipping follows cargoes, although cargoes also follow shipping.

In the context of ever changing economic and logistic systems, each port competes for a share of the traffic generated in its own hinterland and a wider market area. This wider market area is made up of the ports and port hinterlands throughout the world with which it is connected. The outcome depends in part on the relative capacity or quality of five things: (1) ports and their infrastructures; (2) the road, rail and water communications infrastructures linking them with their hinterlands; (3) their maritime interface; (4) their conditions of maritime access; and (5) their cargo handling capabilities. These conditions involve massive investments undertaken ahead of demand. In the case of established ports, they may entail redevelopment and relocation. Cost recovery can take many decades. These investments clearly increase potential connectivity and competitiveness. Yet they remain a gamble, as the 
attraction of shipping also depends on the decisions of international and regional shipping lines that reflect alliances and carrier involvement in the equity of container terminals. After acquiring the port of Piraeus in Greece, COSCO's CEO, Wei Jiafu, said "We have a saying in China, 'Construct the eagle's nest, and the eagle will come'." We have constructed such a nest in your country to attract such Chinese eagles' (cited in Brautigam, 2019). Chinese companies have a significant presence in maritime transport, which is one reason why Chinese invested ports may attract maritime traffic.

At the same time ports and the commercial shipping they seek to attract play an important role in driving down the time and costs of circulation and exchange, reducing transport and related logistic costs, speeding up the turnover of capital and reducing inventories (Dunford and Yeung, 2020). These reductions in freight cost and turnover increase aggregate trade values, alter the composition of trade (Bensassi et al., 2014) and increase income.

As well as helping drive trade and goods traffic, ports and related economic development zones act as growth centres: they create externalities and close input-output relationships, support the growth of value-added and play a role in innovation. In these ways, ports have non-negligeable effects on Gross Domestic Product (GDP) in the regions where ports are located and more widely when planned regional investment in mainland transport systems creates well-connected logistic hubs. Additionally, the quest for maritime security adds a naval dimension to the development of ports and ocean transport, which itself generates incomes and rents.

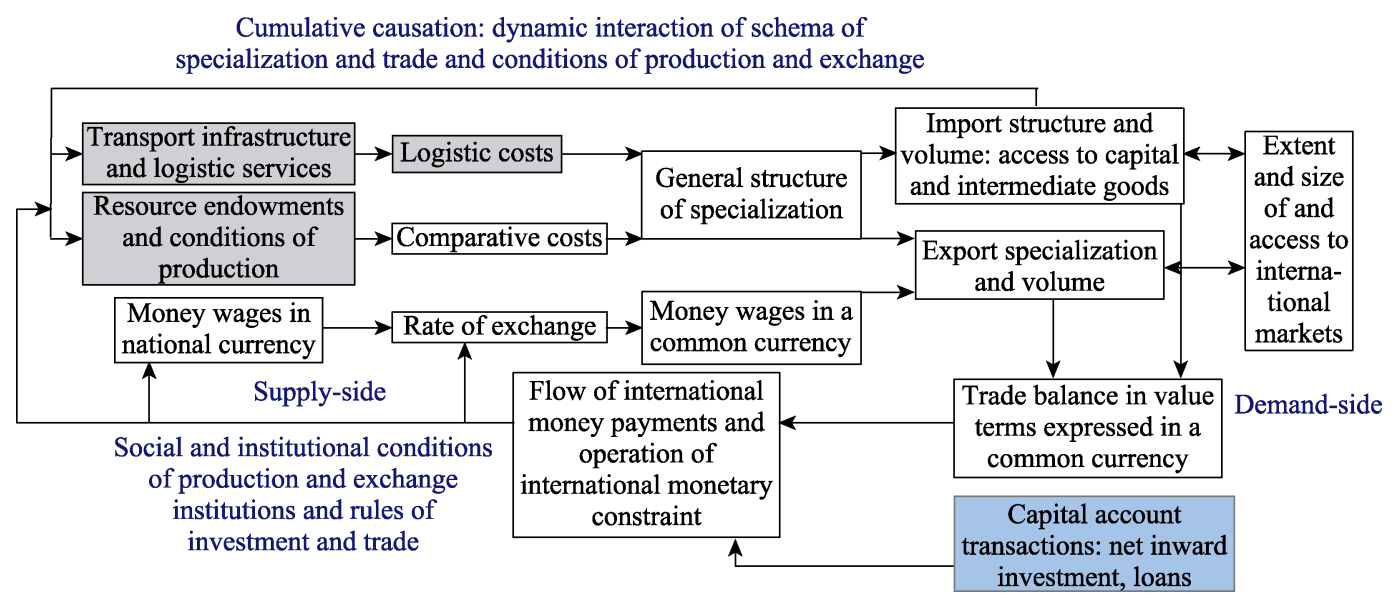

Figure 1 Cumulative causation: conditions of production and exchange, specialization, trade and investment (Source: elaborated from Dunford et al., 2014)

These causal mechanisms underpin the belief that investment in port infrastructures and enhanced connectivity can drive international trade and GDP growth and contribute to processes of circular and cumulative causation (Figure 1). Inward investment and international loans finance port facilities and economic development zones. Enhanced resource endowments and reduced production costs combine with reduced logistic costs to increase export supply capacity and competitiveness. The reduction in logistic costs increases export market potential and export demand, and improves access to imported capital and intermediate goods required to develop infrastructure and productive capacity. A growth in net exports increases GDP and generates income streams that permit repayment of the infrastructure loans and investment that further improves resource endowments, transport infrastructure 
and logistic services which along with money wages determine comparative production and logistic costs.

Changes in national and international conditions can of course affect this dynamic interaction of this schema of specialization and trade, capital movements and the conditions of production and exchange. Accordingly, the aim of this study is to ask whether there is evidence of positive impacts on trade and whether there is a clear relation between trade and GDP in countries with recent Chinese overseas port infrastructure investments, acknowledging that these investments are only one of a multiplicity of factors.

\section{Trade, market potential and supply capacity: gravity principle perspectives}

To examine the relation between port investment, trade and economic development, this research drew on gravity and market potential principles. The concept of market potential dates from an article by Harris (1954). In 1950 the Northeast of the United States accounted for just $12 \%$ of the country's land area but for $50 \%$ of national manufacturing output and $70 \%$ of the industrial workforce. Harris examined the cumulative role of markets and, in particular, of domestic sources of supply of materials and parts in the explanation of this concentration of economic activity. This concept of market potential was closely related to those of economic potential introduced by Clark (1940) and population potential associated initially with Stewart (1947).

These concepts derive from gravity principles whose application to the social sciences was first associated with Carey (1858-9). Gravity principles were subsequently incorporated in Ravenstein's laws of migration (Ravenstein, 1885, 1889), Reilly's law of retail gravitation (Reilly, 1931) and Zipf's principle of least effort (Zipf, 1949). From the late 1950s these ideas were taken up by geographers interested in marketing, transport research, city planning and economic geography (Lukermann and Porter, 1960; Warntz, 1959). Today these principles continue to play a central role in traffic models and are widely used to explore the impacts of transport infrastructure investment and the number, size and quality of logistic services on trade and development, not least as cargo flows are seriously constrained by distance costs (Bottassoet al., 2018).

In the early 1960s gravity and economic potential ideas were taken up by economists interested in international trade (Poyhonen, 1963; Tinbergen, 1962) with a more recent revival of interest associated with economists' renewed interest in economic geography (Bosker and Garretsen, 2012; Redding and Venables, 2003, 2004a, 2004b). In particular, Redding and Venables (2004a) used market potential models to explain the wide international dispersion of wages by geographical distance to overseas markets where a country's exports are sold and that serve as sources of supply of capital and intermediate goods.

In 1999 Hummels (cited in Redding and Venables, 2004a) pointed out that average expenditure on freight and insurance stood at $10.3 \%$ of the value of manufactured exports for the United States, $15.5 \%$ for Argentina and $17.7 \%$ for Brazil, excluding the costs of time and information. This evidence suggests that countries that are distant from markets incur higher transport costs for exported goods and imported equipment and intermediate inputs, so that wages are lower even if technologies are identical. 
In a more recent study, Arvis et al. (2016) showed that in 1992-2010 agricultural and manufacturing trade costs were higher, and manufacturing trade costs decreased more slowly, for low-income countries, with limited maritime transport connectivity playing an important role in driving higher costs. Upper middle-income countries including China were an exception, although in 1992 China was not a member of this group. In China low upstream and downstream trade costs played a major role in its participation in global value chains (Ma and van Aasche, cited in Arvis et al., 2016). A clear implication is that connectivity is an important driver of the rise of emerging economies and that the development of efficient port infrastructures and services able to attract commercial shipping could substantially improve the performance of economically less developed countries.

Harris defined the market potential of a city as the sum of retail sales of each county divided by the transport cost of reaching it from the city in question. In this research, an approach close to that of Redding and Venables (2004a) was adopted. Geographical distance between ports and the capital cities of trade partners provides a rough indication of trade costs. Of course, transport costs also depend on other factors. These factors include the relative share of overland and maritime transport, the trade-off between speed and costs, the number of national border crossings and customs clearances, the commodities transported, the organization of production activities, infrastructural conditions, international connectivity, the extent to which there are regular transport services, logistic organization and tariff and non-tariff barriers. In this study, however, attention was confined to the impedance of distance.

The method adopted involved the estimation of trade equations. The aim was to identify (1) the impact on trade of bilateral distance costs between countries with Chinese overseas ports and all countries in the world and (2) the supply and market capacities of the countries in which these ports are located, defined respectively as

$$
s_{i} d_{i j}^{\theta}, \text { and } m_{j} d_{i j}^{\theta}
$$

where $s_{i}$ denotes the supply capacity of the $i$ th country with a port, $m_{j}$ denotes the market access of the $j$ th trade partner and $d_{i j}^{\theta}, i \neq j$ denotes the distance between the port and the trade partner's capital city, and $\theta$ is a distance decay parameter. In this formulation, $s_{i}$ and $m_{j}$ are exporter and importer fixed effects estimated from the data rather than exogenous indicators of market demand and supply. The export trade relationship between each pair of countries is defined as:

$$
x_{i j}=s_{i} d_{i j}^{\theta} m_{j}
$$

where $x_{i j}$ denotes total exports from county $i$ to country $j$. These estimates were used to estimate $s_{i} d_{i j}^{\theta}$ for each country with a Chinese port, $i$, and $m_{j} d_{i j}^{\theta}$ for each potential partner country, $j$. The results were used to estimate for each country with a Chinese port, market access

and supply capacity

$$
M A_{i}=\sum_{j=1}^{n} m_{j} d_{i j}^{\theta}
$$

$$
S C_{i}=\sum_{j=1}^{n} s_{j} d_{i j}^{\theta}
$$

with, in this case, $d_{i j}^{\theta}$ denoting the distance between the port and the capital cities of all partner countries. 
This model essentially represents the proximity or access of a port to export markets and its capacity to supply exports. Market access is an indicator of market potential, measuring export demand given a port's location relative to its trading partners. Supplier capacity is a measure of the capacity of the port to export to the rest of the world. On the import side a similar distance weighted measure of imports is an indicator of access to imports (ability to import capital and intermediate goods for example) of the port and the hinterland it serves.

To estimate bilateral exports the following econometric specification was adopted:

$$
\ln \left(x_{i j}\right)=\alpha_{1} s_{i}+\alpha_{2} \ln \left(d_{i j}\right)+\alpha_{3} m_{j}+\varepsilon_{i j}
$$

where $x_{i j}$ denotes total exports, supply and demand characteristics were captured, as already indicated, by country, $s_{t}$, and partner, $m_{j}$, dummy variables, $\alpha_{1}, \alpha_{2}$ and $\alpha_{3}$ are parameters to be estimated and $\varepsilon_{i j}$ denotes an error term. (A corresponding formulation was adopted for imports). To avoid collinearity, one of the partner country dummy variables was chosen as a point of reference, while the equation was estimated for each year using OLS regression without a constant term, so as to permit inclusion of dummy variables for all of the countries with ports. In other words, the model estimated was an ordinary least squares model with dummy variables (LSDV) in which the cross-section effects identified in fixed-effect panel data models were modeled using dummy variables. As distance does not vary, time-varying distance coefficients serve as proxies for trade costs and record their evolution.

To check the results, a second simpler trade model was also estimated. This model used national GDP for countries with ports and their trade partners as follows

$$
\ln \left(x_{i j}\right)=\alpha_{0}+\alpha_{1} \ln \left(G D P_{i}\right)+\tau \ln \left(d_{i j}\right)+\alpha_{3} \ln \left(G D P_{j}\right)+\varepsilon_{i j}
$$

where $\left(G D P_{i}\right)$ denotes the GDP of the $i$ th country.

In this research market potential was also estimated using indicators of the impact of the domestic markets of port countries on trade. In this case, $i=j$. Although it is a measure of value added rather than gross output, GDP was used as an indicator of the size of the domestic market, while distance was set equal to the average distance from every point in a circle to all other points, where the circle was the one whose area is equal to the land area of the country concerned. As the emphasis is on the role of ports in international trade, these results are not discussed further in this article, although they were largely consistent with the reported results (with a much inferior fit to the trade data).

To estimate these relationships and to investigate a number of other characteristics of Chinese ports and the countries in which they are located, several data sets were assembled. The first provided information about Chinese overseas ports and was collected from a comprehensive search of public official sources in China and the host countries, international research institutes, Chinese policy and commercial banks and Chinese contractors and was verified by media and other additional sources. A second set of data covered the exports (Free on Board) and imports (Cost Insurance Freight) by a number of broad sectors (total, agricultural products, fuels, ores and metals, manufactures and other) for all countries in the world for which there were COMTRADE data available from the World Bank's World Integrated Trade Solution (WITS) and for most of the individual years from 2007 to 2017. The third set of data related to the real and current GDP and the population of all countries in the world, covering the period from 2000 to 2017. Alongside these data, information on the evolution of commodity prices was derived from World Bank sources. 


\section{The evolution of Chinese overseas ports}

The development of ports and related economic development zones played a central role in the rise of China as the world's second largest economy and as its manufacturing workshop. China has constructed more than 184 new ports since the 1970s. Starting in 2000, Chinese companies were increasingly involved in the construction and acquisition of interests in overseas ports and port, industrial and related residential zones, with parallel initiatives to establish shipping routes and expand the maritime traffic of these ports.

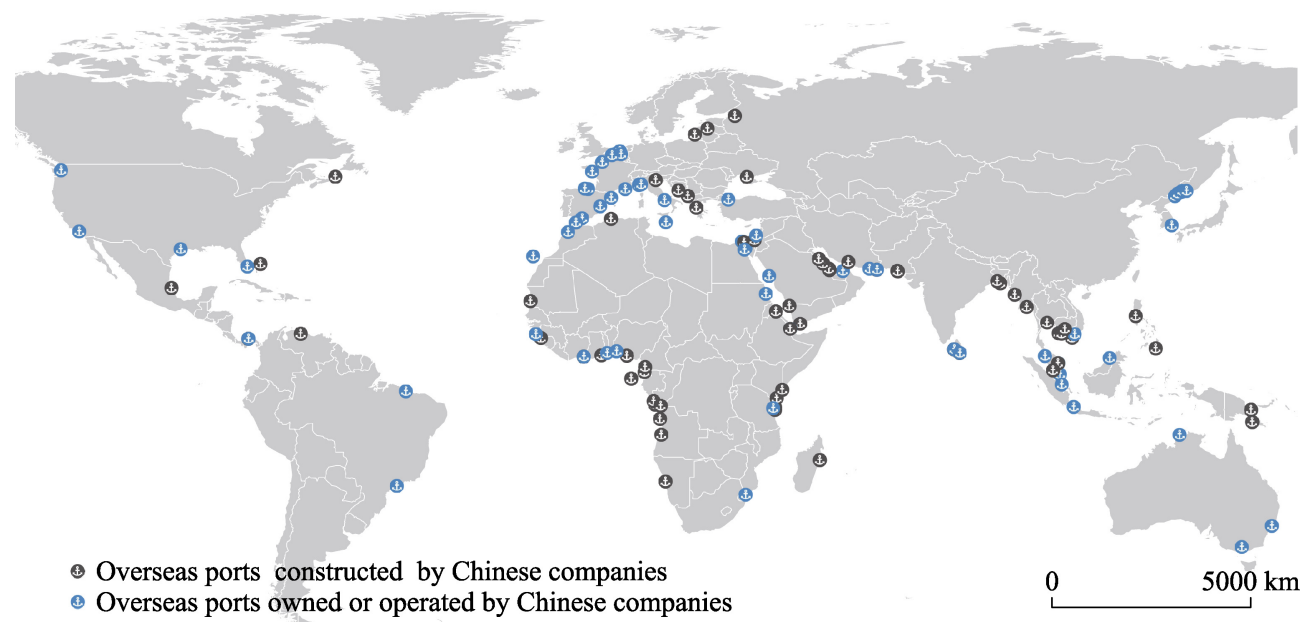

Figure 2 Overseas ports constructed or owned and operated by Chinese companies, 2017 (Source: compiled by the authors from news and company reports)

In April 2019 the Chinese government released a progress report (OLGPBRI, 2019). This report indicated that: Pakistan's Gwadar Port (see Figure 2) had opened regular container liner routes, and that the completion of supporting facilities had attracted more than 30 companies to the Gwadar Free Trade Zone; preliminary work on the industrial positioning and planning of the Sri Lanka's Hambantota Port Special Economic Zone had been completed (see also Brautigam, 2020); an important transit hub had been constructed in the port of Piraeus, and the third phase of port development was about to be completed; the second phase container terminal of the Port of Halifa in the United Arab Emirates was officially opened in December 2018; and China had signed 38 bilateral and regional shipping agreements with 47 countries along the route.

Most of these port investment companies are centrally-owned state-owned companies (SOEs) (see Figure 1). A few of them are local SOEs. One is a private company (Landbridge Group from Shandong Province). Central SOEs are administered by the national StateOwned Assets Supervision and Administration Commission (SASAC), and have much greater political and economic resources than local SOEs and private enterprises. Aided financially by China Development Bank and China's Export-Import Bank, the leading actors include giant SOEs such as China Communications Construction Company (CCCC), China Merchants Group (CMG) and China COSCO Shipping. Smaller state-owned port-related entities like Shanghai International Port Group, and Ningbo Zhoushan Port also play a role.

In some cases, Chinese investment involves the construction of overseas ports under Engineering, Procurement and Construction (EPC), Build, Operate and Transfer (BOT) or Build, Buy, Operate and Transfer (BBOT) contracts. In this case the principal actor is CCCC. 
To date CCCC has been involved in 36 projects. Chinese companies also engage in mergers, acquisitions and joint ventures to acquire an interest in and operate overseas ports. This type of activity principally involves COSCO Shipping, which owns China's largest shipping fleet and at present manages and operates 21 overseas ports, including container terminals in Piraeus and Zeebrugge where it enjoys $100 \%$ control, and CMG which has interests in 20 overseas ports. In a number of cases these projects involve not just the creation of new port facilities but also the establishment of economic development zones.
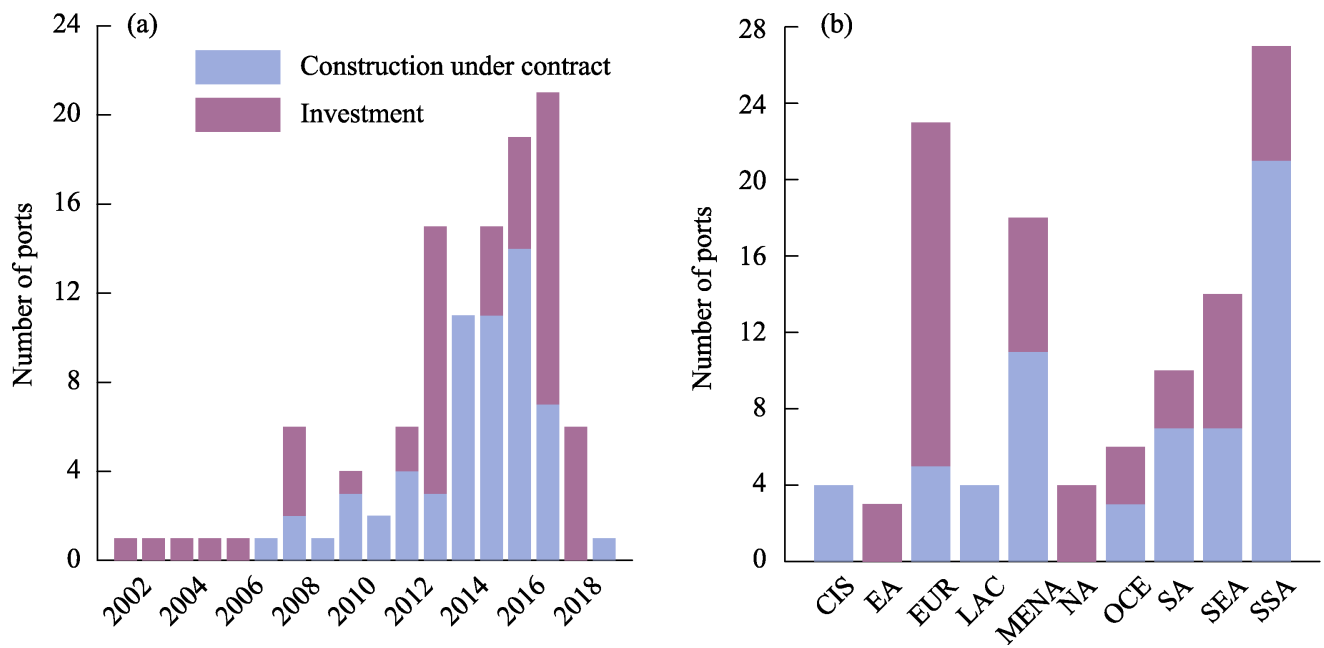

Figure 3 Evolution and geography of Chinese overseas ports

(Source: Chinese ports database. Note: CIS=Commonwealth of Independent States; EA=East Asia; EUR=Europe; LAC $=$ Latin America and the Caribbean; MENA=Middle East and North Africa; NA=North America; OCE $=\mathrm{Oceania}$; $\mathrm{SA}=$ South Asia; SEA=Southeast Asia; SSA=Sub-Saharan Africa)

From 2000 until 2003 Chinese companies started just one new overseas port initiative per year (Figure 3), commencing with the renting by a Hong Kong subsidiary of COSCO of two container terminals in the Port of Los Angeles. The number jumped to 6 in 2008, declined with the western financial crisis and then increased almost continuously from 2012-2017, dropping in 2018.

Investment projects were most numerous in Europe (18), as Figures 2 and 3 show. The overall number of projects was large in Sub-Saharan Africa (27, of which 21 involved construction projects), the Middle East and North Africa (18, of which 11 were construction projects), Southeast Asia (14) and South Asia (10, of which 7 were construction projects).

Clearly, investments were predominantly in ports in developed countries (with an average GDP per capita of USD 24,319 in 2008 and large domestic markets). Construction projects were mainly in developing countries and in particular in low income countries with an average GDP per capita of USD 6,099 (Table 1), suggesting that these projects predominantly helped relatively poor countries that often face considerable difficulties in financing infrastructure projects. In these countries real GDP per capita has increased but not quickly, in part due to strong population growth (Table 1), although the share of world real GDP decreased. If, however, China is excluded, the share of this group increased from $16.9 \%$ in 2008 to $17.1 \%$ in 2017, and the average annual rates of GDP growth for the three groups were $1.98 \%$ (construction), $1.67 \%$ (investment) and 1.92\% (neither). 
Table 1 Gross domestic product, population and trade evolutions of countries with and without Chinese overseas ports (Source: elaborated from Chinese ports database, WITS and World Bank)

\begin{tabular}{|c|c|c|c|c|c|}
\hline & & 2000 & 2008 & 2012 & 2017 \\
\hline \multirow{3}{*}{ GDP share $(\%)$} & Construction contract & 15.0 & 15.5 & 15.5 & 14.9 \\
\hline & Investment & 42.5 & 40.3 & 38.9 & 37.7 \\
\hline & Neither & 42.5 & 44.2 & 45.6 & 47.4 \\
\hline \multirow{3}{*}{$\begin{array}{l}\text { Population share } \\
(\%)\end{array}$} & Construction contract & 23.4 & 24.1 & 24.6 & 25.2 \\
\hline & Investment & 15.9 & 15.7 & 15.6 & 15.4 \\
\hline & Neither & 60.7 & 60.1 & 59.8 & 59.4 \\
\hline \multirow{3}{*}{$\begin{array}{l}\text { GDP per capita } \\
\text { (2010 USD) }\end{array}$} & Construction contract & 5202 & 6099 & 6153 & 6264 \\
\hline & Investment & 21690 & 24319 & 24482 & 25974 \\
\hline & Neither & 5694 & 6966 & 7481 & 8472 \\
\hline \multirow{3}{*}{ Export share (\%) } & Construction contract & 19.7 & 18.2 & 17.5 & 17.3 \\
\hline & Investment & 34.3 & 34.5 & 35.8 & 35.8 \\
\hline & Neither & 45.9 & 47.3 & 46.7 & 46.9 \\
\hline \multirow{4}{*}{ Import share (\%) } & Construction contract & 14.3 & 16.7 & 16.4 & 14.8 \\
\hline & Investment & 40.5 & 38.4 & 37.8 & 39.0 \\
\hline & Neither & 45.1 & 44.9 & 45.8 & 46.3 \\
\hline & & 2008 & 2012 & 2014 & 2017 \\
\hline \multirow{3}{*}{ Agriculture } & Construction contract & 11.0 & 16.5 & 14.9 & 17.1 \\
\hline & Investment & 43.4 & 38.3 & 38.8 & 37.7 \\
\hline & Neither & 45.6 & 45.2 & 46.3 & 45.2 \\
\hline \multirow{3}{*}{ Fuels } & Construction contract & 46.8 & 49.4 & 46.7 & 38.6 \\
\hline & Investment & 23.0 & 22.4 & 22.8 & 26.5 \\
\hline & Neither & 30.2 & 28.2 & 30.6 & 35.0 \\
\hline \multirow{3}{*}{ Manufactures } & Construction contract & 9.4 & 10.5 & 10.5 & 10.7 \\
\hline & Investment & 33.1 & 29.9 & 29.9 & 28.5 \\
\hline & Neither & 57.5 & 59.6 & 59.6 & 60.8 \\
\hline \multirow{3}{*}{ Ores and metals } & Construction contract & 19.8 & 25.1 & 25.5 & 25.8 \\
\hline & Investment & 26.4 & 23.8 & 23.9 & 22.8 \\
\hline & Neither & 53.7 & 51.1 & 50.5 & 51.4 \\
\hline \multirow{3}{*}{ Total exports } & Construction contract & 15.8 & 18.3 & 17.4 & 14.7 \\
\hline & Investment & 32.6 & 30.0 & 30.1 & 29.4 \\
\hline & Neither & 51.6 & 51.7 & 52.5 & 55.9 \\
\hline
\end{tabular}

This study relates to a period starting with the western financial crisis in 2007-2008. As Figure 4 shows, the volume of world trade in current prices continued to increase up to 2013 and then declined, picking up again in 2017, yet remaining lower in current value terms than in 2013. In that same period, the annual nominal prices of commodities reached a peak in 2011 and then declined sharply, with levels in 2017 far beneath the peak values. These movements reflected strong adverse factors driving international trade and a significant deterioration in the situation of natural resource dependent exporters of energy, metals and minerals and agricultural products.

Table 1 also shows that countries in which Chinese companies constructed ports saw their shares of world exports of agricultural products, ores and metals and manufactures increase, although the neither group, which included China, saw the most striking improvement in manufacturing export share. An increase in manufactured exports is of course a possible 

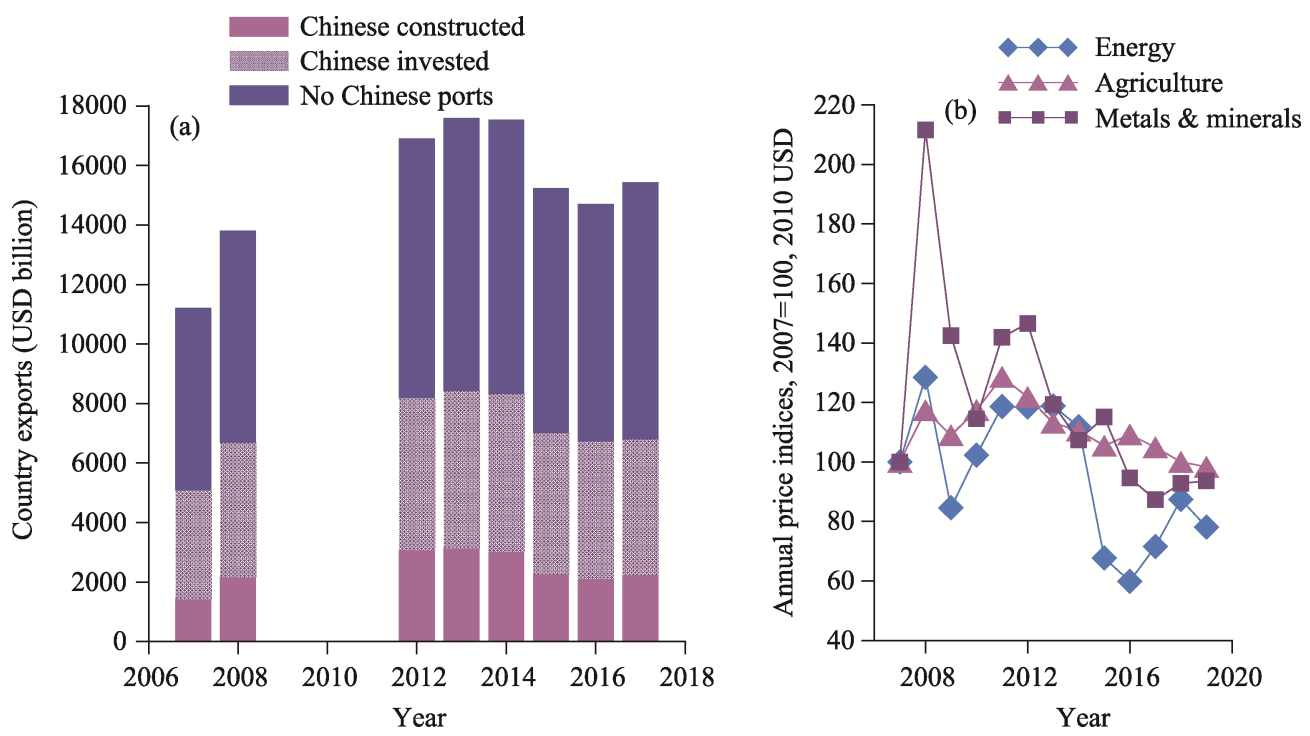

Figure 4 Evolution of world exports in countries with and without Chinese overseas ports and of nominal global commodity prices, 2007-2017

(Source: trade data elaborated from World Bank, WITS, https://wits.worldbank.org/ and World Bank, commodity prices from http://www.worldbank.org/en/research/commodity-markets)

consequence of the development of coastal zones, combining port facilities and industrial growth poles. In 2008 , however, fuels accounted for $44.8 \%$ of the exports of the countries in which China constructed ports. In 2017 this figure stood at just $25.1 \%$. This sharp decline reflects the dramatic decline in fuel prices from 2012 and played an important role in the aforementioned decline in the overall share of world exports.

These port investments were given a strong impetus by the recent evolution of China's economic statecraft and, in particular, by the establishment of China's Belt and Road Initiative (BRI). Many of these ports play significant roles in the Maritime Silk Road and act as nodes connecting maritime routes with overland infrastructure investment (Chin, 2015; Dunford and Liu, 2019; Lin et al., 2019; Liu and Dunford, 2016).

As this section has indicated, these investments were made in difficult time for the world economy. However, data in Table 1 suggest that, in these years, the countries in which China constructed ports made progress in a number of respects. The high income markets in which investment occurred saw relative decline. If China is removed, the group of countries in which there were no Chinese overseas ports drops behind the countries in which China constructed ports in terms of real GDP growth. As already mentioned, however, the aim of this research was to identify national effects. The aim was not to compare countries with Chinese ports with other countries or with a counterfactual representing the past performance of the countries concerned not least as the world trade situations were radically different.

\section{Trade, market potential and supply capacity estimation}

As already mentioned the value of bilateral exports (and imports) in the trade equations depends on the supply (market) capacity of the exporter (importer), the market capacity (supply capacity) of the importer (exporter) and bilateral transport costs, represented in this case simply by distance between host capital cities and ports and capital cities of trade partners (see also Figure 1 for a representation of the more detailed causal connections). These sup- 
ply and demand capacities were captured by dummy variables. As the study deals with ports, attention was not paid to whether countries are or are not landlocked nor to adjacency, as is common in the mainstream economics literature on this subject.

In the matrix of bilateral trade flows there were a significant number of missing entries. The existence of missing values could reflect the fact that particular trade flows were in fact zero. Nevertheless, observation of the series for total flows suggests that in some cases values were missing, especially as in a few cases zero values were actually recorded. In these circumstances, and, in the first instance, a value of one was added to all zero trade flows measured in US dollars before taking logarithms (the logarithm of one is zero).

Redding and Venables (2004a) initially used OLS. Arguing however that trade data are left-censored at zero, the model was re-estimated using a Tobit estimator. If negative observations are left-censored at zero, the Tobit coefficients are consistent (yielding a higher slope coefficient). However, these coefficients reflect not just the impact of the independent on the (above zero values of the) dependent variable but also the probability of being above the censored value. The appropriateness of this method depends on whether rounding up of zero flows is significant. Certainly zeros do not reflect unobservable negative trade flows that would warrant this approach.

Zero flows do exist however as pairs of countries do not trade with each other, especially if data are disaggregated by commodity. Asymmetric flows are also common, while the number of countries that trade with each other tends to increase over time. To deal with issues arising from these considerations, a number of methods aim to address the selection bias associated with the non-random elimination of zeros from trade matrices. A two-stage approach proposed by Heckman (1979) was adopted in which the probability of trade is estimated first, using a probit regression, and a trade model is then estimated for trading countries (see for example Bosker and Garretsen, 2012). This approach was extended by Helpman et al. (2008). The aim was to deal not just with the non-random elimination of zeros, when estimating a logarithmic gravity model, but also with the bias associated with omission of the effect of productivity thresholds on trade (see Figure 1). In this approach the first step involves the use of a probit regression to estimate the probability of a decision of two countries to trade with each other (called the extensive margin). The second step involves estimating a logarithmic gravity equation using the predicted probabilities obtained in the first step to estimate the effects on trade volume (called the intensive margin). A difficulty with this approach is identifying the characteristics of countries and pairs of countries that affect the propensity to trade but do not affect its volume.

Variation in the density of the matrices does affect the estimated coefficients. As a result, the analyses of export and import evolutions reported in this article involved a number of adjustments. First, in cases where there were positive values for trade in certain sectors and no total trade value, the sectoral components were added up to estimate the total. Second, where there were total values for 2007 and not for 2008 and for 2016 and not for 2017, the 2007 and 2016 values were used. Third, cases where bilateral trade was still recorded as zero before and after these adjustments were dropped from the analysis of evolutions. In each case, the impact of the adjustments was observed. The main consequence was a reduction in the relative scores for recent years, as occurred in the case of estimates of export market potential. 
Table 2 reports the results of estimating export and import flows in 2008, 2012 and 2017 using OLS with the full trade matrix (no excluded cases in the first ten rows and six columns of results) and for a trade matrix with no missing values in 2008 and 2017 after using 2007 and 2016 data to fill gaps. The equations were estimated for other years, but these years were chosen as start (2008), end (2017) and middle (2012) of several years that were turning points in commodity prices and trade volumes. In each case the coefficient of distance was negative and statistically highly significant (a probability of 0.0000 under the null hypothesis that the distance coefficient was equal to zero in each and every case). In the case of imports and exports, the distance coefficient increased from 2008 to 2012 and then declined (a trend also reflected in regressions for intermediate years) indicating an increase followed by a decrease in the impedance of distance and an overall decrease from 2008 to 2017.

Table 2 Estimating trade models for countries with Chinese overseas ports, 2008-2017

\begin{tabular}{|c|c|c|c|c|c|c|}
\hline Data used & $\begin{array}{c}\text { Dependent } \\
\text { variable }\end{array}$ & Year & $\begin{array}{l}\text { Coefficients of } \\
\text { distance }\end{array}$ & $\begin{array}{l}\text { Adjusted } \\
R \text {-squared }\end{array}$ & $\begin{array}{c}\text { Reporter dummies } \\
\text { (of } 61 \text { number not } \\
\text { significant) }\end{array}$ & $\begin{array}{l}\text { Partner dummies (of } \\
205 \text { number not } \\
\text { significant) }\end{array}$ \\
\hline \multirow{6}{*}{$\begin{array}{l}\text { Full trade } \\
\text { matrix }\end{array}$} & $\ln$ (exports) & 2008 & $-1.6537 * * *$ & 0.8813 & 15 & 0 \\
\hline & & 2012 & $-2.1889 * * *$ & 0.8948 & 1 & 0 \\
\hline & & 2017 & $-1.5850 * * *$ & 0.9025 & 18 & 0 \\
\hline & $\ln$ (imports) & 2008 & $-1.5257 * * *$ & 0.8769 & 17 & 0 \\
\hline & & 2012 & $-1.9156^{* * *}$ & 0.9050 & 6 & 0 \\
\hline & & 2017 & $-1.3294 * * *$ & 0.9030 & 14 & 1 \\
\hline \multirow{4}{*}{$\begin{array}{l}\text { Revised trade } \\
\text { matrix }\end{array}$} & $\ln$ (exports) & 2008 & $-2.0107 * * *$ & 0.9691 & 12 & 0 \\
\hline & & 2017 & $-1.4228 * * *$ & 0.9706 & 14 & 0 \\
\hline & $\ln$ (imports) & 2008 & $-1.5447 * * *$ & 0.9811 & 6 & 0 \\
\hline & & 2017 & $-1.5160 * * *$ & 0.9806 & 0 & 0 \\
\hline
\end{tabular}

*Significant at $10 \%, * *$ Significant at $5 \%$, ***significant at $1 \%$.

This result is what one might expect if the construction of new infrastructures from 2012 had significant impacts on national accessibility to markets for exports and imports, though it will also reflect trends in the value of trade. The null hypothesis that the coefficients of the dummy variables were equal to zero was rejected by an F test (significant at the 0.0001 level), and the models remarkably explained at least $88 \%$ of the variation in the dependent variables in the case of the full trade matrix and more than $98 \%$ in the case of the matrices with no missing values. ${ }^{1}$

\section{Evolution of export market potential, export supply capacity and access to imports of countries with overseas Chinese ports}

The next step was to use the coefficients estimated from the model (and the coefficients from the GDP models) to estimate the export market potential of each port, their export supply capacities and their access to imports (using for these estimates the distance from the port to capital cities of partner countries). In this case, of course, what is estimated is the role

\footnotetext{
${ }^{1}$ In the case of estimates using reporter and partner GDP rather than dummy variables, the signs of the estimated coefficients were all correct, and the independent variables were all statistically significant.
} 
only of foreign markets. As already mentioned, models including the domestic market (domestic supply to domestic markets and domestic demand for domestic products) were also estimated, but, as the trade model did not provide estimates of domestic distance impedance, a different formulation outlined earlier had to be used.

An attempt was made to map the geography of economic potential and its evolution. The export reporter (countries with ports) scores for different years were highly correlated, as were the partner fixed effects. As one might expect, the export market potential of partners was closely correlated with their import supply potential. The difficulty is that the values vary with the density of the matrix of trade flows. To deal with this problem, the comparisons rest on export market potential, export supply capacities and access to imports computed for matrices with positive trade flows. The results are however similar to those derived from the full trade matrix and from matrices in which sums of sectoral components of trade for 2007 and 2016 values were used as estimates of missing total, 2008 and 2017 bilateral exports and imports.

The export market potential and supply capacity scores are plotted in Figure 5 and are very striking. The left-hand side of Figure 5 plots computed foreign market potential of countries with Chinese overseas ports in 2008 and 2017. In the first place it is clear that geographical location has a significant impact on access to markets. Oceania and North America recorded low scores. As already mentioned this research concentrated on foreign market demand. Although these countries are distant from other parts of the world, they are large and/or high-income countries with large domestic markets. The overall market potential of these countries is high due to high domestic demand: it is the exclusion of domestic
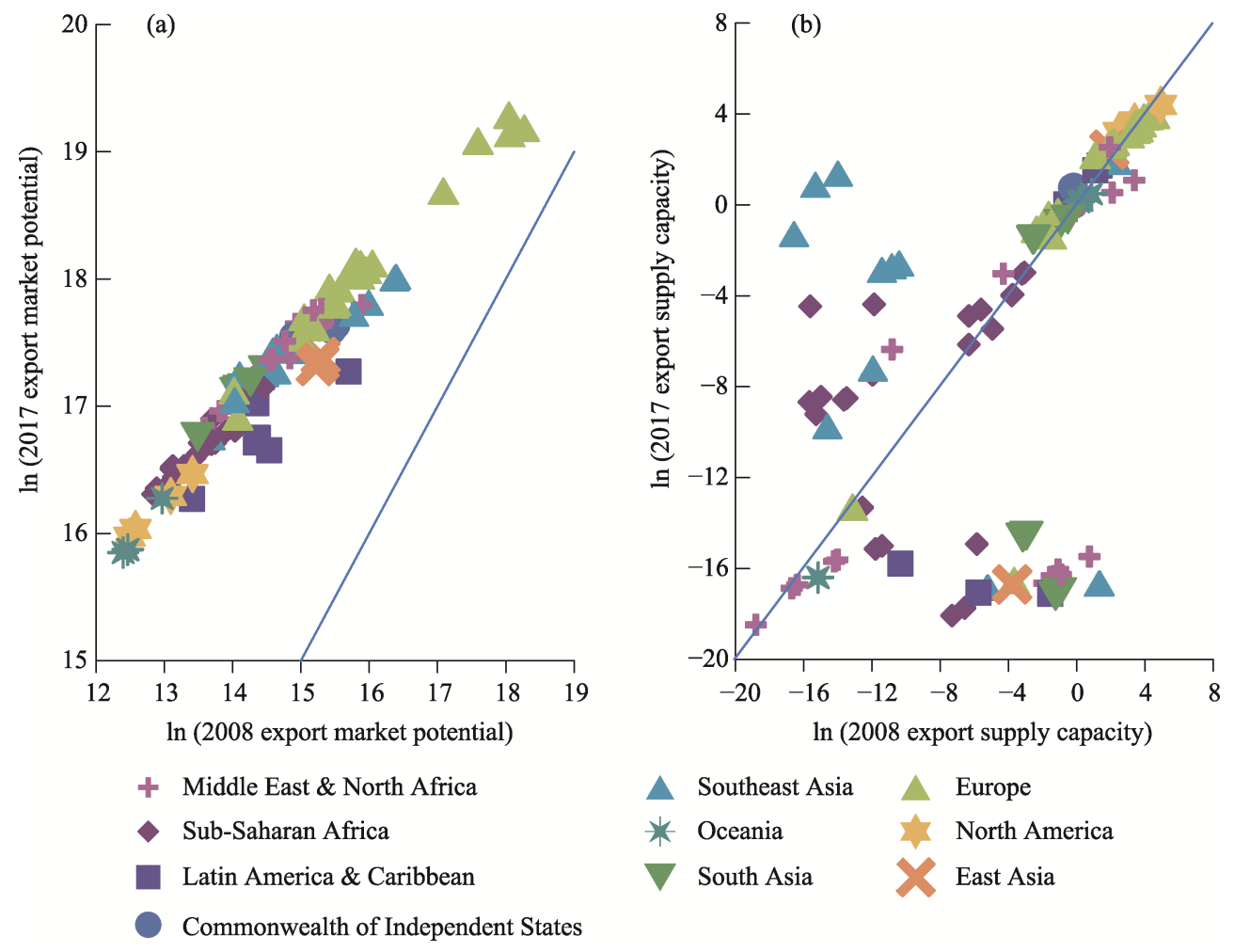

Figure 5 Foreign market potential and supply capacity of Chinese overseas ports, 2008 to 2017 
The $45^{\circ}$ line indicates a significant increase in market potential for all of the ports in 2008 to 2017. These increases reflected the overall decline in the distance impedance factor reported in Table 2, but the improvements were greater for ports with lower market potential with some relatively striking improvements in a number of ports in Southeast Asia, South Asia and Sub-Saharan Africa where closer trade ties were clearly reflected in increases in reporter fixed effects.

In the case of supply capacity (right-hand side of Figure 5), a significant number of ports lay close to a $45^{\circ}$ line. Almost all European ports and the ports in North America had high export supply capacity scores, with only very small relative increases or declines in 2008-2017, reflecting the relative stagnation of economically advanced economies. The main exceptions were Piraeus in Greece, Klaipeda in Lithuania and Riga in Latvia. Six out of ten ports in South Asia and all seven in Latin America and the Caribbean also lay beneath the $45^{\circ}$ line. In each case, specific factors were at work. A striking outlier was the oil port of Puerto Cabello in Venezuela. In this case the imposition of sanctions by the United States prevented Venezuela from selling oil to its largest market. It also prevented it from obtaining the naptha that it needs to dilute and sell its heavy oil. At the same time the decline in oil prices played a significant role. To help offset these problems, the Chinese government signed oil for loan deals, and the Russian Federation sought to enable Venezuela to export its oil. The port of Sao Luis in Brazil also lay just under the $45^{\circ}$ line. In this case construction by a consortium led by CCCC only started in 2018. This port is designed mainly to export grain, and the project is connected with the development of a logistics corridor for agricultural products from the state of Maranhão. About 50\% of ports in Sub-Saharan Africa, conversely, saw improvements in their relative export supply capacity. In addition, Southeast Asia and especially in Malaysia, Myanmar and the Philippines saw striking improvements in their overall capacity to supply exports to international markets. In the Middle East and North Africa, relative supply capacity generally declined in an area subject to considerable turbulence.

The relationship between the scores in 2012 and 2017 differ. Distance impedance declined from -1.93 in 2012 to -1.50 in 2017 but the recorded volume of world exports declined, and in these circumstances market potential scores diminished (left-hand side of Figure 6). The decline was the greatest for ports in European countries with high market potential scores. These countries are of course major world markets, whose stagnation had adverse effects on the countries supplying them with exports. The right hand side of Figure 6 shows however that the improvements in supply capacity of the Chinese overseas ports and their hinterlands were much more general and significant in the years after 2012. Very strikingly the export supply capacity of a substantial share of ports in Sub-Saharan Africa increased in these years, suggesting relatively effective export-oriented restructuring of their economies.

In 2008-2017 there was also a large increase in access to imports (import supply potential), as is indicated on the left-hand side of Figure 7. On the demand side, however, the capacity to absorb imports (import demand potential) diminished, except in the case of a few ports and countries in Sub-Saharan Africa where there were small increases (right-hand side of Figure 7). For a number of ports in emerging countries in Southeast Asia, declines were relatively small. 

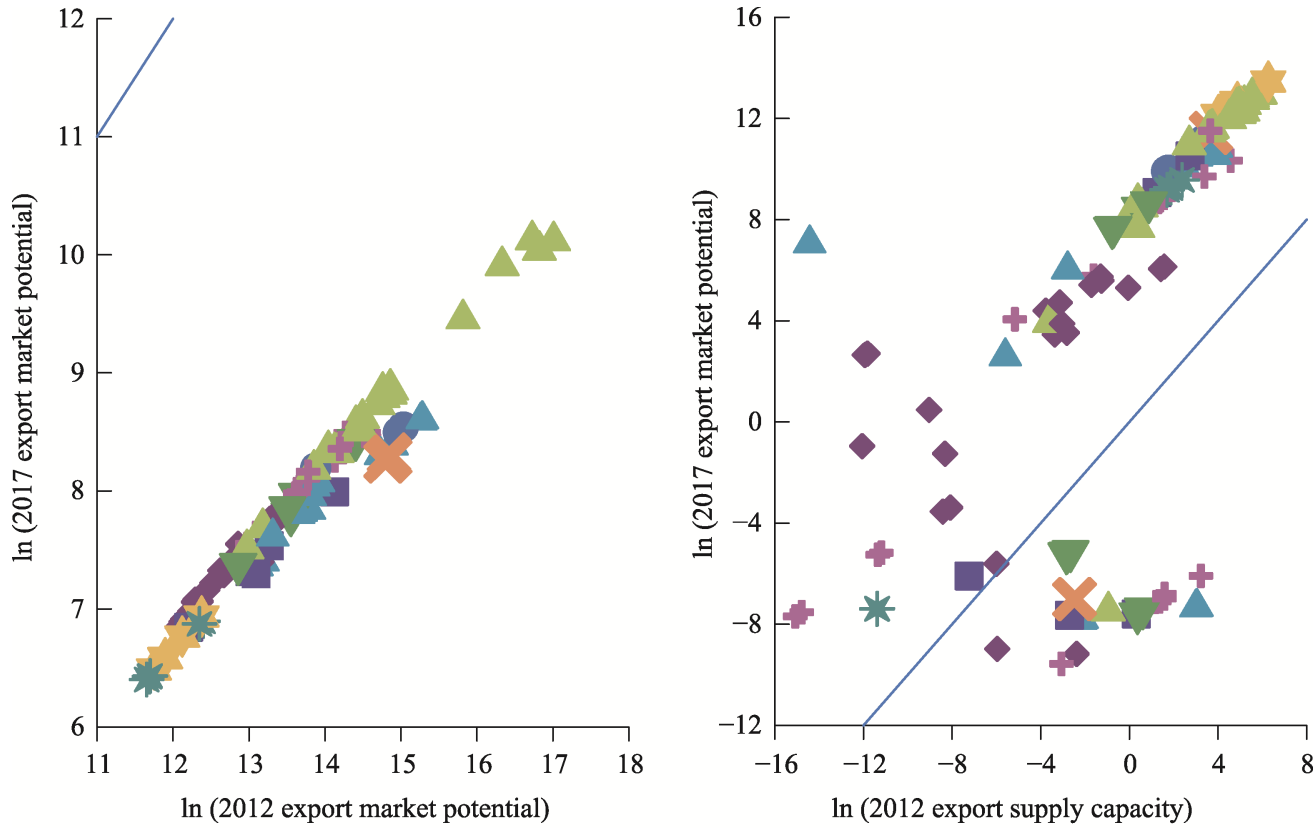

$+\quad$ Middle East \& North Africa

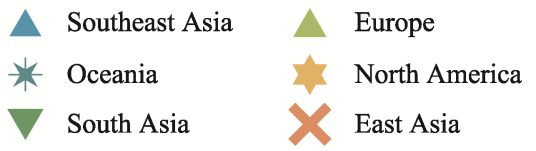

Sub-Saharan Africa

Latin America \& Caribbean

Commonwealth of Independent States

Figure 6 Foreign market potential and supply capacity of Chinese overseas ports, 2012 to 2017
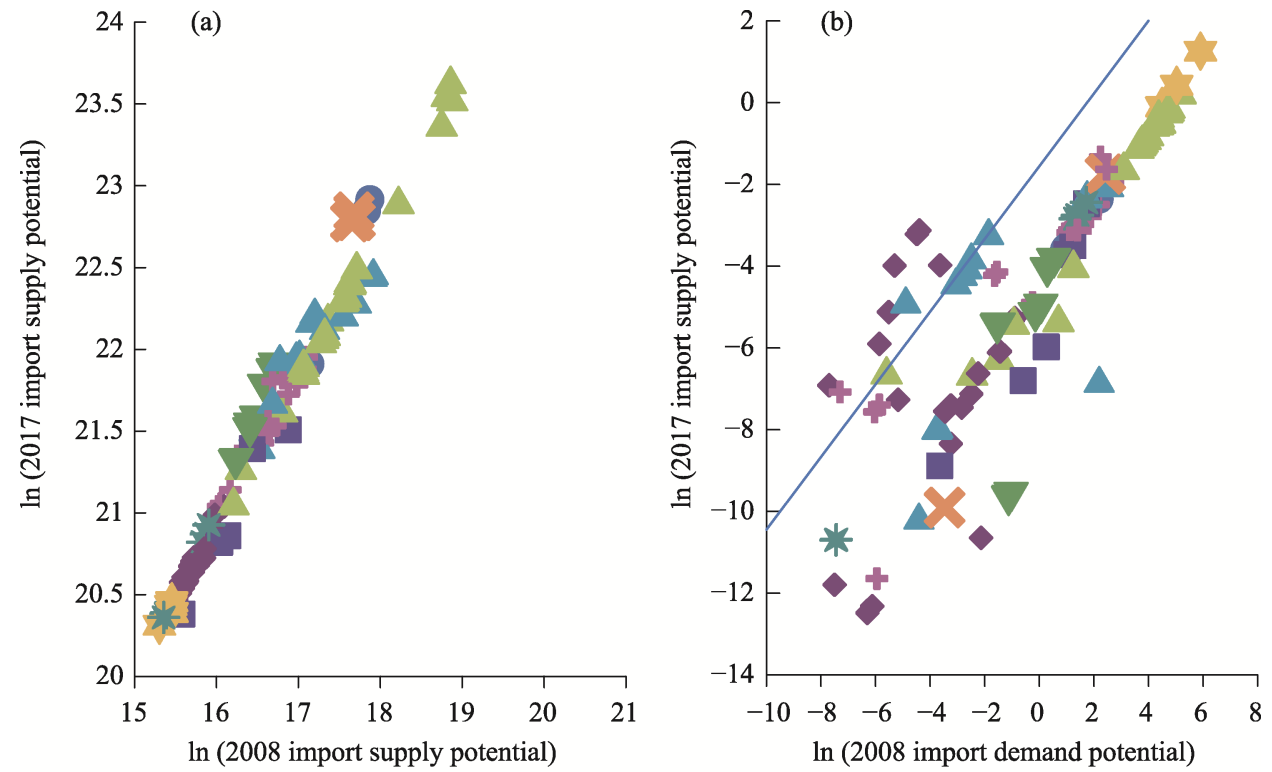

Middle East \& North Africa
Sub-Saharan Africa
Latin America \& Caribbean
Commonwealth of Independent States

\begin{tabular}{lll}
$\triangle$ Southeast Asia & \multicolumn{1}{|c}{ Europe } \\
$*$ Oceania & North America \\
$\nabla$ South Asia & East Asia
\end{tabular}

Figure 7 Import supply and demand potential, 2008-2017 
As indicated earlier, Chinese overseas port investments accelerated after 2012. At the same time it is important to remember that many of the impacts of major infrastructure take years to emerge, and that many factors are at working in driving national trajectories. As in the case of export data, Figure 8 reflects the decline in global trade after 2012. What is particularly striking, however, is that the absorption of imports (import demand potential) increased in 2012 to 2017. This increase was fairly general but with a number of Southeast Asian $^{2}$ and African ports and countries standing out. This result is consistent with the idea that the capacity of these countries to acquire imported capital, intermediate and consumer goods increased, while the creation of new markets in emerging economies is also an ambition of the extension of the march of Asian modernization to under-developed Asian and African countries that find it extremely difficult to get loans and acquire capital and intermediate goods to modernize their economies.

Market potential and supply capacity are important drivers of income (see, for example, Redding and Venables, 2004a). Figure 9 plots the relationship between per capita GDP in 2017 and market potential (left-hand side) and supply capacity (right-hand side). North America and Oceania are, as already noted, parts of the world that are remote from foreign markets. However, strong domestic demand and high supply capacity help explain high incomes. Countries with Chinese ports that are centrally located (mainly in Europe) also have high incomes per capita, while countries that are remote with few neighbours or with neigbours that are economically small with low market potential have low incomes per capita.
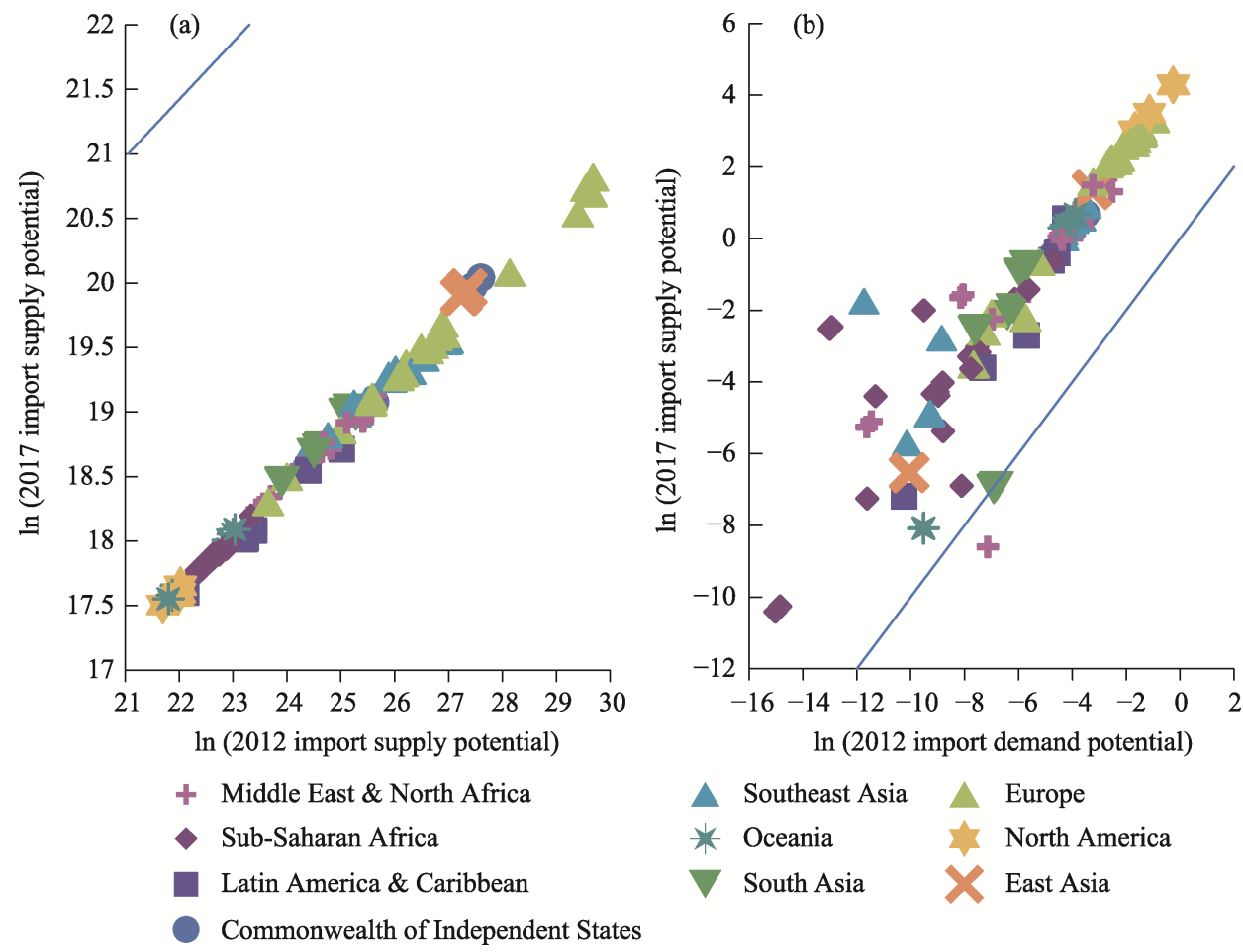

Figure 8 Import supply and demand potential, 2012-2017

\footnotetext{
${ }^{2}$ Indonesia is, for example, an archipelago with over 17,000 islands. A 2014 national government project to transform Indonesia into a 'Global Maritime Axis' requires the development of ports and shipping channels to which BRI projects can contribute.
} 

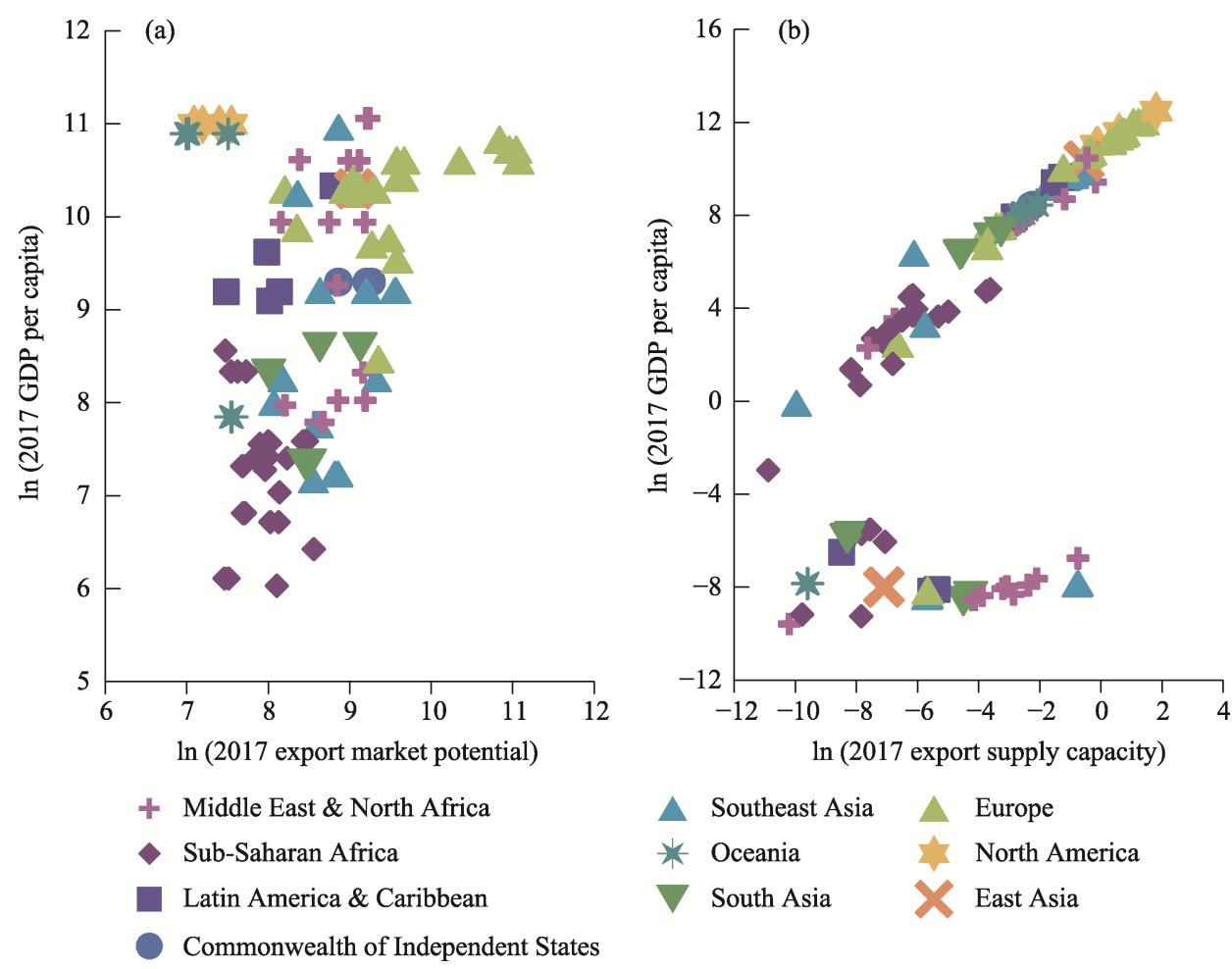

Figure 9 Market potential, supply capacity and per capita GDP, 2017

Table 3 reports the results of two regressions of the natural logarithm of GDP per capita on those of the market potential and supply capacity indicators plotted in Figures 5 and 6 (export model) and the import side indicators in Figures 7 and 8 (import model). In the first case, the coefficient of multiple determination is 0.204 , the $\mathrm{F}$ statistic is highly significant

Table 3 GDP per capita, market potential, supply capacity and foreign import access, 2017

\begin{tabular}{lcc}
\hline & $\begin{array}{c}\text { Export } \\
\text { model }\end{array}$ & $\begin{array}{c}\text { Import } \\
\text { model }\end{array}$ \\
\hline $\ln (2017$ Foreign market demand potential) & $0.486 * * *$ & \\
$\ln (2017$ Foreign market supply capacity) & $0.059 * * *$ & \\
$\ln (2017$ Foreign partner supply capacity) & & 0.213 \\
$\ln (2017$ Foreign import access) & & $0.300^{* * *}$ \\
Constant & $4.542 * * *$ & $5.480^{* *}$ \\
F & $13.330^{* * *}$ & $42.110^{* * *}$ \\
$R$-squared & 0.204 & 0.447 \\
\hline
\end{tabular}

*Significant at $10 \%, * *$ significant at $5 \%$, ***significant at $1 \%$ and the coefficients of the two independent variables are positive as expected. The independent variables are however correlated (0.205) albeit weakly. Although the Variance Inflation factors are only a little greater than one, the coefficients should be treated with caution. Correlation coefficients show however that the impact of supply capacity is relatively more important, while partial correlation coefficients indicate its considerable importance for any given level of market potential. The second regression generates stronger results. The coefficient of multiple determination is 0.447 . Both coefficients are positive, but only the second is statistically significant. The zero-order (and partial) correlation coefficients are 0.355 $(0.151)$ and $0.659(0.607)$ for the two independent variables. This result suggests that the actual absorption of imports or capacity to absorb imports was closely related to income per 
capita: while in some cases it may reflect high income and high effective demand for imports, it is nonetheless also what happens with the implementation of major infrastructure projects that bring with them access to imported capital and intermediate goods. As mentioned earlier, in the years after 2012 the absorption capacity of a number of emerging economies increased quite strongly.

As these results show, the development of Chinese overseas port infrastructures has gone hand in hand with increases in export (foreign) market potential since 2012, and, in the case of a significant share of countries with ports, in export supply capacity. These two factors are generally associated with increases in income, although it must be emphasized that these results derive from the interaction of a wide range of factors: the impedance of distance, the evolution of international trade, infrastructural investment that facilitates trade and the redeployment of the economies of ports and their hinterlands. In somewhat inauspicious times for international trade, a reduction in the impedance of distance, increases in export supply capacity and increased availability of imported goods (capital, equipment and consumer goods) are however what one might expect from investment in improved port and related logistic infrastructures, although these investments do of course constitute only a part of the overall investments that drive the evolution of economies, varying in size with the size of the projects and the levels of national economic development.

\section{Conclusions}

For many countries, exports and access to capital equipment and intermediate goods are important drivers of growth. However, these drivers are strongly affected by geographical location, the impedance of distance and underlying transport and infrastructural conditions that influence transport and logistic costs. Geographical remoteness and high logistic costs affect the cost of a country's exports in foreign markets, as well as the costs they must pay for supplies of capital and intermediate goods, sourced mainly from the more developed economies of the United States, Western Europe and East Asia and needed to increase export supply capabilities. Ad valorem transport and communications costs paid by countries that are remote or close only to weakly developed countries and that lack infrastructure reduce the incomes they can pay even with similar technologies.

In the recent past Chinese companies have started to invest in overseas ports. Chinese investment has occurred in low income countries largely dependent on commodity exports but whose sustainable development also requires the development of manufacturing industries. Investment has also occurred in high income countries with large domestic markets. China's own trade with these countries is large, and investments in port infrastructures can be expected not just to give a strong local short-term economic stimulus but also in the longer term to reduce trade costs and stimulate stronger economic development.

The aim of this research was to use macro-geographical methods to identify trends in export market economic potential, export supply capacity and the availability of imports for the countries in whose port development China has started to participate. At this very 
early stage the impacts of these investments lie mainly in the future. Trends in export potential, supply capacity and capital and intermediate goods availability are however causes as well as effects potentially contributing to virtuous spirals of circular and cumulative causation (see Figure 1), as China's own experience shows (Dunford, 2017; Lin, 2017).

Since its announcement in 2013 these Chinese investments have assumed roles in China's BRI which aims to improve infrastructural and regulatory connectivity, increase international commerce and investment, establish growth poles and deepen and transform international economic co-operation. Investments in major infrastructures such as ports do of course carry risks: environmental risks associated with pollution and ecosystem damage, political risks as, for example, governments change and risks associated with debt. Managing these risks is a vital governance concern.

The gravity models with country fixed effects used to estimate exports and imports were particularly effective, accounting for extremely high shares of the variation in the independent variables. The coefficients were used to estimate export market potential, supply capacity and the availability of imported goods. In this period as a whole the volume of trade rose and fell with little overall increase in its current value, economically advanced economies largely stagnated and from the middle of this period commodity prices fell dramatically. Over the period as a whole the foreign market potential of these ports and countries increased, although it largely declined from 2012 to 2017. In this latter period, import demand potential increased. More strikingly, in 2008 to 2017 export supply capacity, which is an important driver of GDP per capita, increased in many of countries in which these ports are located, particularly in Southeast Asia and Sub-Saharan Africa. After 2012 these increases were especially striking and were also recorded in some parts of the Middle East and North Africa and in Europe. In a period in which the prices of fuels and minerals and metals fell, the low-income countries chosen for port construction projects saw increases in their share of world manufactured exports, suggesting that processes of industrialization were under way.

A number of other studies found positive impacts of infrastructure on trade and growth. Redding and Venables (2004a) found that access to markets and sources of supply are statistically significant and quantitatively important in explaining international differences in per capita income. Arvis et al. (2016) found that maritime transport connectivity and trdae facilitation along with regional trade agreemensts are important determinants of trade costs. Bosker and Garretsen (2012) observed a positive effect of market access on economic development in Sub-Saharan Africa. Munim and Schramm (2018) surveyed a range of studies studied 91 countries with seaports. Arguing that positive impacts of seaport investments are often questioned sometimes in recent studies, they showed that the quality of port infrastructure and logistics were important determinants of seaborne trade and economic growth especially in developing countries.

As emphasized on several occasions, the aim of this study was to identify the evolution of a number of drivers of trade and income. The economic potential indicators all reflect macroeconomic changes in port hinterlands that depend on far more than a particular infrastruc- 
tural investment. No claims are therefore made about the impacts of these projects themselves. The study simply identifies some evolutions that are consistent with aspects of improved trade performance to which port infrastructures might contribute. Indeed, one might argue that it is the aspects of potential trade improvement that made the investments themselves attractive. Causes are often effects and effects are often causes.

Nor were any major comparative claims made: the evolution of the same indicators for the heterogeneous countries in which there are no Chinese overseas ports was not estimated, while comparisons with the same ports in the years up to 2008 would relate to a radically different global economic context. A number of comparisons were reported however in Table 1. The comparative indicators show that the developed countries in which China acquired ports lost ground. However, these markets remain exceptionally important. Most strikingly there is evidence that, in difficult times, the predominantly low income countries in which China constructed ports made some progress in a number of respects, especially if China itself is excluded: the share of this group of world GDP increased from 2008 to 2017 and the average rates of real GDP growth for the three groups were: $1.98 \%$ (construction); $1.67 \%$ (investment); and 1.92\% (neither).

This study does raise a number of questions about methodologies and in particular the estimation of gravity models. In economics a great deal of attention is paid to statistical issues associated with the estimation of gravity models. Almost all of these issues relate to deriving population estimates from random samples. One might hypothesize that the only sense in which recorded trade data is a sample is that trade is subject to measurement error. In that case issues do relate to the handling of missing values and the existence of zero trade flows.

Clearly long-term analyses of individual cases are required to explore causes and consequences of Chinese construction of, and investment in, overseas ports. A macro perspective is important as it enables cases to be placed in a wider context and enables some assessment of the representativeness/consistency of individual evolutions. The methods used in this research are of considerable value in examining this context, especially once projects have been completed. These methods could also be employed in a more comprehensive comparative study.

\section{References}

Arvis J F, Duval Y, Shepherd B E N et al., 2016. Trade costs in the developing world: 1996-2010. World Trade Review, 15(3): 451-474.

Bensassi S, Martinez-Zarzoso I, Suarez C, 2014. The effect of maritime transport costs on the extensive and intensive margins: Evidence from the Europe-Asia trade. Maritime Economics \& Logistics, 16(3): $276-297$.

Bosker M, Garretsen H, 2012. Economic geography and economic development in Sub-Saharan Africa. World Bank Economic Review, 26(3): 443-485.

Bottasso A, Conti M, Porto P C D et al., 2018. Port infrastructures and trade: Empirical evidence from Brazil. Transportation Research Part A: Policy and Practice, 107(6): 126-139.

Brautigam D, 2019. Misdiagnosing the Chinese infrastructure push. https:/www.the-american-interest.com/2019/ 04/04/misdiagnosing-the-chinese-infrastructure-push/.

Brautigam D, 2020. Debt-trap diplomacy: The rise of a meme. Area Development and Policy, 5(1): 1-14.

Carey H C, 1858-9. Principles of Social Science. Philadelphia: J. R. Lippincott and Co.

Chin G T, 2015. China's bold economic statecraft. Current History, 114(773): 217-223. 
Clark C, 1940. The Conditions of Economic Progress. London: Macmillan.

Ducruet C, Itoh H, Joly O, 2015. Ports and the local embedding of commodity flows. Papers in Regional Science, 94(3): 607-627.

Dunford M, 2017. The rise of China and its implications for economics and other developing countries: The significance of the Chinese social model. Area Development and Policy, 2(2): 124-129.

Dunford M, Liu W, 2019. Chinese perspectives on the Belt and Road Initiative. Cambridge Journal of Regions, Economy and Society, 12(1): 145-167.

Dunford M, Yeung G, 2020. Development, regional, port-industrial complexes. In: Kobayashi A (ed.), International Encyclopedia of Human Geography. 2nd ed., 3: 271-280, Elsevier.

Dunford M, Liu W D, Liu, Z G et al., 2014. Geography, trade and regional development: The role of wage costs, exchange rates and currency/capital movements. Journal of Economic Geography, 14(6): 1175-1197.

Harris C D, 1954. The market as a factor in the localizatin of industry in the United States. Annals of the Association of American Geographers, 44(4): 315-348.

Heckman J J, 1979. Sample selection bias as a specification error. Econometrica, 47(1): 153-161.

Helpman E, Melitz M, Rubinstein Y, 2008. Estimating trade flows: Trading partners and trading volumes. Quarterly Journal of Economics, 123(2): 441-487.

Lin J Y, 2017. The rise of China and its implications for economics and other developing countries. Area Development and Policy, 2(2): 109-119.

Lin S, Sidaway J D, Woon C Y, 2019. Reordering China, respacing the world: Belt and Road Initiative (一带一路) as an emergent geopolitical culture. The Professional Geographer, 71(3): 507-522.

Liu W D, Dunford M, 2016. Inclusive globalization: Unpacking China's Belt and Road Initiative. Area Development and Policy, 1(3): 323-340.

Liu Z G, Schindler S, Liu W D, 2020. Demystifying Chinese overseas investment in infrastructure: Port development, the Belt and Road Initiative and regional development. Journal of Transport Geography, 87(7): 1-10.

Lukermann F, Porter P W, 1960. Gravity and potential models in ecnomic-geography. Annals of the Association of American Geographers, 50(4): 493-504.

Munim Z H, Schramm H J, 2018. The impacts of port infrastructure and logistics performance on economic growth: The mediating role of seaborne trade. Journal of Shipping and Trade, 3(1): 1-19.

Office of the Leading Group for Promoting the Belt and Road Initiative (OLGPBRI), 2019. The Belt and Road Initiative: Progress, contributions and prospects. http://www.xinhuanet.com/2019-04/22/c_1124400071.htm.

Poyhonen P, 1963. A tentative model for the volume of trade between countries. Weltwirtschaftliches Archiv: Review of World Economics, 90(1): 93-100.

Ravenstein E G, 1885. The laws of migration. Journal of the Royal Statistical Society, 48: 167-227.

Ravenstein E G, 1889. The laws of migration. Journal of the Royal Statistical Society, 52(2): 241-301

Redding S, Venables A J, 2003. South-East Asian export performance: External market access and internal supply capacity. Journal of the Japanese and International Economies, 17(4): 404-431.

Redding S, Venables A J, 2004a. Economic geography and international inequality. Journal of International Economics, 62(1): 53-82.

Redding, S, Venables A J, 2004b. Geography and Export Performance: External Market Access and Internal Supply Capacity. Chicago: Universtiy Chicago Press.

Reilly W J, 1931. The Law of Retail Gravitation. New York: Knickerbocker Press.

Robinson R, 2002. Ports as elements in value-driven chain systems: The new paradigm. Maritime Policy \& Management, 29(3): 241-255.

Stewart J Q, 1947. Empirical mathematical rules concerning the distribution and equilibrium of population. Geographical Review, 37(3): 461-485.

Tinbergen J, 1962. An analysis of world trade flows. In: Tinbergen J (ed.). Shaping the World Economy. New York: Twentieth Century Fund.

UNCTAD, 2019. Review of maritime transport 2018. https://unctad.org/en/pages/PublicationWebflyer.aspx? publicationid $=2245$.

Warntz W, 1959. Progress in economic geography. In: James P E (ed.), New Viewpoints in Geography (Twenty-Ninth Yearbook of the National Council for the Social Studies), 54-75. Washington D.C.: National Council for the Social Studies.

Zipf G K, 1949. Human Behaviour and the Principle of Least Effort: An Introduction to Human Ecology. Cambridge, MA: Addison-Wesley. 